\title{
Characterization of solid waste in the permanent preservation area of the Bate Estacas stream, Porto Velho, Rondônia
}

Permanent Preservation Areas serve as filters to prevent impurities from reaching water bodies, protecting the banks from erosion, avoiding the obstruction of rivers caused by waste dumped in inappropriate places. The present study aimed to inventory, quantify, and analyze the types of solid waste irregularly deposited on the banks and in the Bate Estacas stream in Porto Velho, Rondônia. The Bate Estaca stream is approximately $6.5 \mathrm{~km}^{2}$ long, covering the Cohab, Castanheira, Caladinho, and Aeroclube neighborhoods. The data collection was conducted in plots located in isolated tree stretches, approximately 100 meters long, in the stream's Permanent Preservation Areas. The plots' dimensions were $10 \times 10$ meters, separated by a distance of 10 meters, totaling three plots. This study presented data on the composition and average weight of solid waste in Permanent Preservation Areas, associated with urban streams in Porto Velho's municipality. We recorded almost 3 tons of waste in $300 \mathrm{~m}^{2}$, with plastic being the dominant item in quantity and construction material in weight. The irregular disposal is a result of the lack of inspection, basic sanitation, and knowledge of the residents living near the stream about the importance of these areas.

Keywords: Discard; Diseases; Construction material; Plastic.

\section{Caracterização dos resíduos sólidos da área de preservação permanente do riacho Bate Estacas, Porto Velho, Rondônia}

As Áreas Preservação Permanentes servem como filtro para evitar que impurezas alcancem as porções d'água, protegendo as margens contra erosão, evitando a obstrução dos rios causada por resíduos despejados em locais inapropriados. O presente trabalho teve como objetivo inventariar, quantificar e analisar os tipos de resíduos sólidos depositados irregularmente nas margens e no leito do igarapé Bate Estaca na cidade de Porto Velho, Rondônia. $O$ igarapé Bate Estaca tem aproximadamente $6,5 \mathrm{~km}^{2}$, abrangendo os bairros Cohab, Castanheira, Caladinho e Aeroclube. Foram definidos dois pontos de coletas. A coleta de dados foi conduzida em parcelas em dois trechos isolados, de aproximadamente 100 metros de comprimento, sendo as parcelas alocadas na APP do igarapé. As dimensões das parcelas eram de $10 \times 10$ metros, com uma distância entre parcelas de 10 metros, totalizando três parcelas. O presente estudo apresentou dados sobre a composição e peso médio de resíduos sólidos em APP, associadas a igarapés urbanos do município de Porto Velho, registrando-se quase 3 toneladas de resíduos em $300 \mathrm{~m}^{2}$, sendo o plástico o item dominante em quantidade e o material de construção em peso. O descarte irregular decorre da ausência de fiscalização, inexistência de saneamento básico e da ausência de conhecimento dos moradores que residem próximo ao igarapé sobre a importância dessas áreas.

Palavras-chave: Descarte; Doenças; Material de construção; Plástico.

Topic: Conservação da Biodiversidade

Reviewed anonymously in the process of blind peer.
Received: 02/03/2021

Approved: 24/05/2021
Cláuber Muniz de Oliveira

Centro Universitário Aparício Carvalho, Brasil

http://lattes.cnpq.br/9258894578501766

clauber44@gmail.com

Alexandre Henrique de Sousa Lima

Centro Universitário Aparício Carvalho, Brasil

http://lattes.cnpq.br/8904017547689509

alexandrhenrique2015@gmail.com

Marcela Álvares Oliveira (iD

Centro Universitário Aparício Carvalho, Brasil

http://lattes.cnpq.br/9346965102777187

http://orcid.org/0000-0002-4129-993X

marcela.mugrabe@gmail.com
Referencing this:

OLIVEIRA, C. M.; LIMA, A. H. S.; OLIVEIRA, M. A.. Characterization of solid waste in the permanent preservation area of the Bate Estacas stream, Porto Velho, Rondônia. Nature and Conservation, v.14, n.2, p.22-32, 2021. DOI: http://doi.org/10.6008/CBPC23182881.2021.002.0003 


\section{INTRODUCTION}

Brazilian environmental legislation prioritizes the preservation/conservation of natural resources. The development of society must be sustainable, respecting the population's current needs but not affecting the supply of resources to fulfill the needs of future generations (ROMEIRO, 2012; OJEDA et al., 2013). To this end, and to ensure the quality of life and protection of all forms of life, Special Protected Territorial Spaces should be created to provide this protection (BRASIL, 1988). Among these spaces, we highlight urban Permanent Preservation Areas (PPAs). The PPAs have protected areas that, according to articles 2 and 3 of the Forest Code (BRASIL, 2012), consist of territorial spaces that can be public or private, urban or rural. They are characterized as containing native or non-native vegetation, functioning to preserve water resources and the biodiversity of fauna and flora, geological stability, soil protection, and the welfare of adjacent populations (BRASIL, 2012).

The conservation and recovery of PPAs, due to their extreme importance for biodiversity, is essential for the maintenance of environmental comfort in urban areas, guaranteeing pleasant humidity and air temperature for the fauna and the population living around them (SCHÄFFER et al., 2011). PPAs act as filters preventing impurities from reaching water resources and are of great importance for reducing urban environmental risks (GUIMARÃES et al., 2017; CASTRO et al., 2018). In this way, they protect banks against erosion and avoid the obstruction of rivers caused by solid waste dumped in inappropriate places, which causes flooding.

Thus, PPAs are of great importance maintaining environmental balance, whether located in rural or urban areas, where they play a protective role so that water resources are not contaminated, and the quality of the environment is not degraded (BORGES et al., 2011). Their maintenance involves challenges ranging from their installation, maintenance, handling, and administration (BENSUSAN, 2006). This becomes especially challenging in urban areas that exert significant pressure on these forested areas, since these spaces provide multiple functions to the surrounding populations (MOREIRA et al., 2019).

However, in the current scenario, with the significant growth and advance of populations, natural resources are suffering from deforestation and other anthropic disturbances. This generates an imbalance in ecosystems (BARBOSA et al., 2014), which can usually be related to the absence of knowledge regarding the importance of the environment to the organisms that inhabit it (SCHÄFFER et al., 2011). The state of Rondônia follows the same unstructured form of urban growth which occurs across Brazil (NASCIMENTO et al., 2012). In this state, the environment's natural characteristics are also not considered, generating an absence of infrastructure and planning and resulting in negative impacts on the quality of life in the urban environment (BEZERRA et al., 2012; SZEREMETA et al., 2013; LONDE et al., 2014). With population growth, these areas suffer from increased pressure and consequently, the extent of vegetation cover is drastically reduced due to extensive anthropic constructions (BILAC et al., 2014).

Since the beginning of urbanization, significant changes have been made to the natural landscape, causing the degradation and destruction of natural resources (ROSSI et al., 2012; SILVA et al., 2015; GARCIA 
et al., 2018). Even with the current conceptions of environmental protection, the damage caused by the unstructured occupation of urban areas are apparent (SILVA et al., 2015). Among these damages, we highlight the risks of lack of sanitation, rupture of water bodies, loss of water quality, and soil fragility of these irregularly occupied areas (ZÜNDT, 2006). The lack of correct destinations for human secretions, sewage, sanitary and stable waste, favors water being carried through the drainage network or by water currents, causing visible severe problems, such as dark-colored water, odors, and high levels of nutrients from decomposing organic matter (ROSSI et al., 2012).

Therefore, when considering the current state of urban PPAs it was noted that a field study on solid waste disposal was required in these environments, with the knowledge that in adequate waste disposal due to different factors, especially nearby housing. Thus, this research had a guiding question: What is the composition and average weight of the solid waste discarded in the Urban Permanent Preservation Area of the Bate Estacas stream?

\section{METHODOLOGY}

The municipality of Porto Velho is the third-largest capital of the Northern region and the largest in the state of Rondônia. Its population in 2020 was estimated at 539354 inhabitants, with a population density of 12.57 inhabitants $/ \mathrm{km}^{2}$, predominantly urban. It presents $42.8 \%$ of domiciles with adequate sanitary exhaustion, $40 \%$ of urban domiciles on public roads with forestation, and $21.7 \%$ of urban domiciles on public highways with adequate urbanization (IBGE, 2020). The municipality has approximately 69 neighborhoods with different levels of urbanization, most of which developed without any planning (SILVA et al., 2017)

The stream, Bate Estacas, is part of the Madeira basin located on this river's right bank. The mainstream comprises the micro bay of Bate Estacas, which covers an area of approximately $113 \mathrm{~km}^{2}$ and 18 $\mathrm{km}$ of linear extension. The total area of the stream is $12 \mathrm{~km}^{2}$. It is located in the southern zone of the city of Porto Velho/RO, which is characterized by having the lowest density of streams in the city (SILVA et al., 2017). Its drainage area within the urban perimeter of Porto Velho cuts across seven neighborhoods, the main points being the Japanese road, through the Areia Branca road, until it meets the Madeira River.

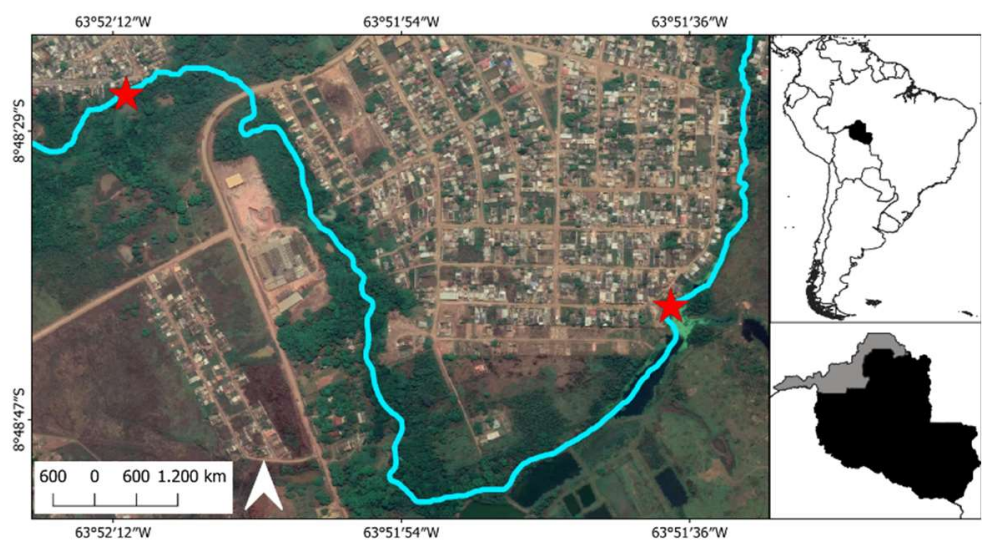

Figure 1: Locations of the sampling plots in the Permanent Preservation Area of the Bate Estacas stream in Porto Velho/RO. 
Similarly, regardless of the PPAs in the city (SILVA et al., 2017), there is a vegetation deficit and several areas with irregular constructions (invasions), which dispose of their household waste directly into the stream. In the case of solid waste, although there is regular garbage collection in the region, the resident populations of the invaded areas dispose of their garbage on the margins and bed of the stream.

Data collection was conducted on three plots of two isolated stretches, approximately 100 meters long, within the PPAs of the Bate Estacas stream in the Caladinho and Aeroclube neighborhoods (Figure 1).

The dimensions of the plots were $10 \times 10$ meters, with a distance of 10 meters between them. Each plot was considered as an independent sampling event. Within the defined space of each plot, all the solid residues observed were counted and classified. For the classification of waste, eight categories were defined and the grouping criteria were determined by the main component of waste composition or type. Later the average weight in kilos of each item was calculated from the information available from different manufacturers on the Internet (Table 1).

Table 1: Categorization of solid waste recorded in the urban portion of the Permanent Preservation Area of the Bate Estacas stream in Porto Velho/RO.

\begin{tabular}{|c|c|c|}
\hline Category & Item & Average weight (kg) \\
\hline \multirow{8}{*}{ Plastic } & Pet bottle & 0.047 \\
\hline & Vessels in general & 0.115 \\
\hline & $C D$ & 0.03 \\
\hline & Toy & 0.75 \\
\hline & Bag & 0.003 \\
\hline & Potty & 0.23 \\
\hline & Styrofoam & 0.424 \\
\hline & PVC pipe & 5.34 \\
\hline \multirow{2}{*}{ Paper } & Cigarette Butt & 0.00006 \\
\hline & Cigarette box & 0.03 \\
\hline \multirow{7}{*}{ Metal } & Aerosol & 0.088 \\
\hline & Refrigerator grid & 1.08 \\
\hline & Pieces of iron bars & 1 \\
\hline & Beer cans & 14.5 \\
\hline & Paint cans & 3 \\
\hline & Parabolic antenna & 42 \\
\hline & Chair & 6 \\
\hline \multirow{2}{*}{ Glass } & Glass bottles & 0.3 \\
\hline & Lamps & 0.002 \\
\hline \multirow{5}{*}{ Household appliances } & Televisions & 28 \\
\hline & Refrigerators & 65 \\
\hline & Washing machine & 10 \\
\hline & Mobile & 0.11 \\
\hline & Fan & 7.48 \\
\hline \multirow{3}{*}{ Clothing } & Sandal & 0.18 \\
\hline & Clothes & 0.2 \\
\hline & Shoes & 0.24 \\
\hline \multirow{3}{*}{ Construction material } & Bricks & 2.2 \\
\hline & Sewage and rainwater shackle & 261500 \\
\hline & Ceramics & 1.125 \\
\hline \multirow{5}{*}{ Other } & Baby stroller & 12 \\
\hline & Umbrella & 0.57 \\
\hline & Motorbike helmet & 1.4 \\
\hline & Soccer ball & 0.4 \\
\hline & Car tire & 2 \\
\hline
\end{tabular}

The average weight of the "Building Material" category was calculated from each registered item's volume. The same applies in the case of PVC pipes and iron bars. For the calculation of the other items, the 
average weight of popular equipment/products, which are more accessible to the medium and low-income population, was considered. For the data analysis, the absolute frequency of units and weight of each category were calculated. The median was used to determine the number of registered companies and weight in each sample. Data collection was carried out between September and November of 2019, including the end of the dry season. Each plot was visited only once to avoid recounts.

\section{RESULTS}

During the data collection, it was possible to note the lack of vegetation and that the local population uses the stream for recreational activities, including fishing and the use of fire for the disposal of waste in general. It was also possible to observe that the irregular dwellings have piping systems that discharge liquid waste directly into the water body (Figure 2).

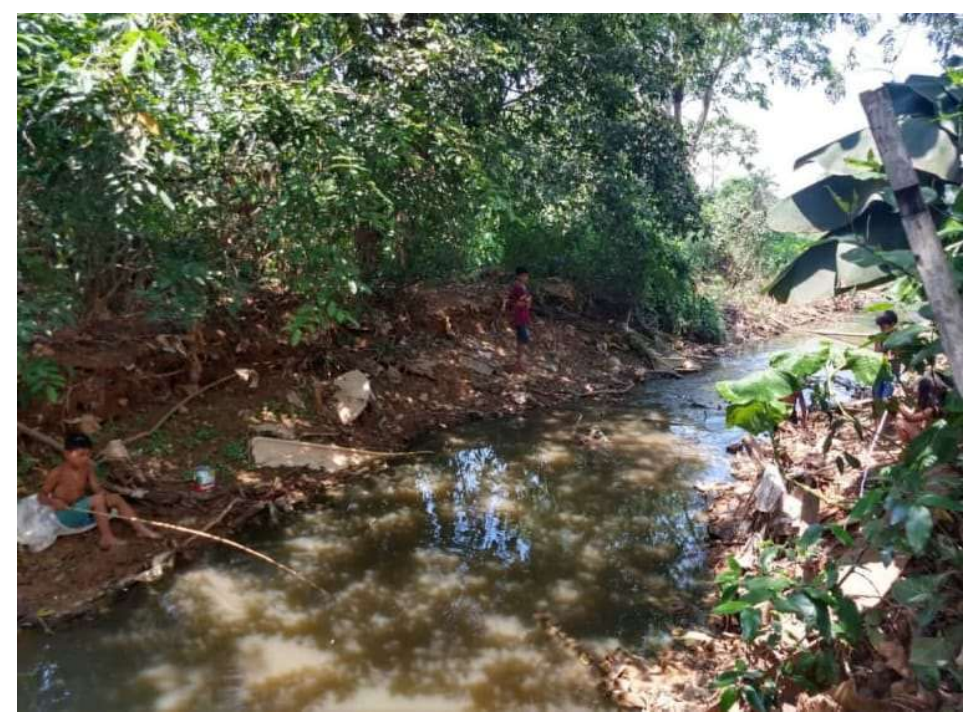

Figure 2: Bate Estacas stream in the southern area of Porto Velho/RO.

Five hundred and ninety-eight items and 2615786.7436 kilos were recorded in $300 \mathrm{~m}^{2}$ (Figure 3). The median number of units registered in each plot was 186, and the median weight was 1201.532 kilograms. A simple extrapolation of the average weight found in this stretch to the rest of the stream area predicts approximately $104.640 \times 10^{5}$ kilograms of solid waste. Excluding the construction material, this value would be approximately $27.920 \times 10^{7}$ kilograms (Table 2 ).

Table 2: Quantification and weight of solid waste recorded in the urban portion of the Permanent Preservation Area of the Bate Estacas stream in Porto Velho/RO.

\begin{tabular}{llll}
\hline Category & Item & Quantity & Weight (kg) \\
\hline \multirow{4}{*}{ Plastic } & Pet bottle & 105 & 4.935 \\
& Vessels in general & 20 & 2.3 \\
& CD & 8 & 0.24 \\
& Toy & 3 & 2.25 \\
& Bag & 195 & 0.585 \\
& Potty & 1 & 0.23 \\
\multirow{2}{*}{ Paper } & Styrofoam & 34 & 14.416 \\
& PVC pipe & 11 & 58.74 \\
\hline \multirow{2}{*}{ Metal } & Cigarette Butt & 10 & 0.0006 \\
& Cigarette box & 8 & 0.24 \\
\hline & Aerosol & 1 & 0.088
\end{tabular}




\begin{tabular}{|c|c|c|c|}
\hline & Pieces of iron bars & 12 & 12 \\
\hline & Beer cans & 4 & 58 \\
\hline & Paint cans & 2 & 6 \\
\hline & Parabolic antenna & 1 & 42 \\
\hline & Chair & 1 & 6 \\
\hline \multirow{2}{*}{ Glass } & Glass bottles & 27 & 8.1 \\
\hline & Lamps & 2 & 0.004 \\
\hline \multirow{5}{*}{ Household appliances } & Televisions & 8 & 224 \\
\hline & Refrigerators & 2 & 130 \\
\hline & Washing machine & 6 & 60 \\
\hline & Mobile & 1 & 0.11 \\
\hline & Fan & 1 & 7.48 \\
\hline \multirow{3}{*}{ Clothing } & Sandal & 4 & 0.72 \\
\hline & Clothes & 44 & 8.8 \\
\hline & Shoes & 4 & 0.96 \\
\hline \multirow{3}{*}{ Construction material } & Bricks & 25 & 55 \\
\hline & Sewage and rainwater shackle & 10 & 2615000 \\
\hline & Ceramics & 27 & 30.375 \\
\hline \multirow{5}{*}{ Other } & Baby stroller & 2 & 24 \\
\hline & Umbrella & 1 & 0.57 \\
\hline & Motorbike helmet & 2 & 2.8 \\
\hline & Soccer ball & 1 & 0.4 \\
\hline & Car tire & 10 & 20 \\
\hline
\end{tabular}

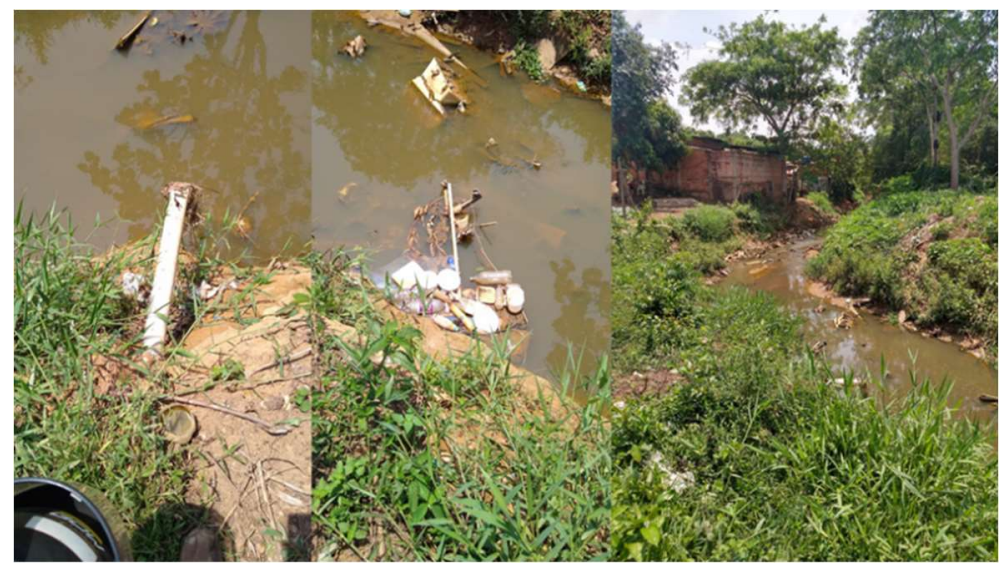

Figure 3: Overview of the solid waste discarded in the urban portion of the Permanent Preservation Area of the Bate Estacas stream in Porto Velho/RO.

The "Plastic" category registered 377 units, which is equivalent to $63.04 \%$ of the total. These values were impelled by the items "plastic bag" and the "pet bottle", which together represent $50.17 \%$ of the items found, adding 300 units. Concerning the weight, although representing only $1.67 \%$ of the units found, the construction material represented $99.97 \%$ of the total weight registered in the area (Figure 4).

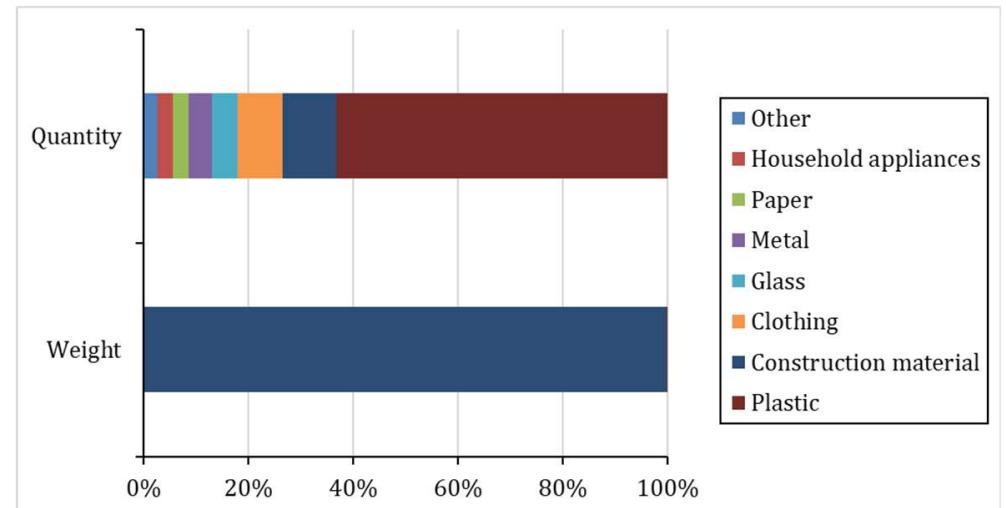

Figure 4: Quantity of solid waste units registered per item in the urban portion of the Permanent Preservation Area of the Bate Estacas stream in Porto Velho/RO. 


\section{DISCUSSION}

This study presents the first data on the composition and average weight of solid waste in PPAs associated with urban streams in Porto Velho's municipality, registering almost 3 tons of waste in $300 \mathrm{~m}^{2}$. Regarding the general aspects of PPAs, we can highlight the absence of vegetation and fishing. The deficit of vegetation in the PPAs is due to the lack of characterization caused by road and land works, which have already caused the disappearance of part of the drainage channels (CPRM, 1997), besides the irregular constructions. The suppression of vegetation is one of the significant anthropic impacts observed in urban green areas (SILVA NETO et al., 2016; SANTOS et al., 2019; RODRIGUES et al., 2020).

Fishing activity favors the direct contact of the population with the stream water. According to Nova et al. (2019), the most common diseases found in people living in these environments are dengue, chikungunya, and diarrhea. Sampaio et al. (2012), when studying populations located in the at-risk areas of the Grande stream's microbasin, found the most common diseases to be malaria and dengue fever. This was thought to be as a result of the physical and biological conditions of the site, both due to the presence of residues on the edges of the channel that serve as shelter and larval procreation, and the incidence of still water. The absence of basic sanitation and the irregular disposal of waste thrown into the stream bank and its body of water favors the development of these diseases. The populations of invaded areas and stream surroundings dispose of solid waste in the streets or at the bottom of backyards which are directly connected to the stream, resulting in the accumulation of a large amount of waste and the collection of stagnant water which contributes to the presence of the dengue mosquito.

The accumulation of solid residues present in these areas can attract insects and animals and generate disease vectors for the populations living nearby (ARAÚJO et al., 2016). Other factors which attributed to waste are soil, air, and water pollution (SILVA et al., 2008). Inorganic products found in the study PPAs that take long periods of time to decompose, such as glass, paper, plastics, metals, and rubber stand out in our results. The decomposition time of the most common waste category, plastic, is 400 years whereas glass, one of the rarest items observed here, is 1,000 years. The different solid residues found in the Bate Estacas stream cause significant urban environmental impacts, as once these residues are carried to the stream bed, they are transported by the current and accumulate along the way. With the arrival of the rainy season and the possibility of overflowing, this problem becomes even more significant, since this waste can occupy public roads, and in more extreme situations, the homes of the surrounding population. Consequently, the water drainage system could suffer an overload due to blockages, generating an even more critical situation and with a greater chance of registering zoonoses, such as leptospirosis. The accumulation of this type of waste in an inadequate location attracts wild vectors that seek shelter, food, and water.

Uchôa et al. (2013), when characterizing solid waste disposal in the Pricumã stream in Boa Vista/Roraima, found that this activity caused partial silting, interfering with the current and water levels as well as changing the natural flow of the stream. Moreover, according to the authors, the population also 
made improper use of the ecosystem, causing vegetation suppression. A similar situation is found in the Bate Estacas stream, where floods are common in the rainy season. The category "Construction material" items can favor such silting, due to their weight and deposition at the bottom of the bed. The disposal of "Construction Materials," although representing the highest registered weight, may result from scrap disposal from construction sites near the study locations and may be an occasional record.

A study conducted by Pereira et al. (2018) in Manaus/AM, verified that the inadequate disposal of solid waste does not happen uniformly in the city and that the construction materials cause this occasional behavior. Shackles are used to construct underground wells and sewage and rainwater drainage systems; thus, it is essential to investigate the origin of these products for proper accountability. Reports of discarding materials used in public construction sites in inappropriate locations have already been registered in Porto Velho. The inadequate disposal of construction materials causes soil pollution and consequently results in the degradation of the landscape that preserves lives and comprises public health threats.

The study by Santos et al. (2014) in Caranã stream in Boa Vista/Roraima highlights that the major impacts that occurred in the stream were due to the construction of a residence near the source, resulting in the tearing down of morichi palms and the disposal of solid, organic and inorganic waste. Another problem in the Caranã stream is the disposal of solid and liquid waste, for example, plastic bags, bottles and sewage pipes. The same impacts can be observed in the Pile Beater stream due to the similarity between the disposal and usage profiles observed.

Plastic bags and pet bottles were the most frequently observed waste items around the stream and generate public problems, such as the blockage of drains which prevents the correct drainage of water. These types of waste are the most common and have the highest disposal rate due to the ease of obtaining them, for example from supermarkets and logistics establishments, because the population uses these items mainly as containers for the disposal of waste from different sources. Plastic is comprised of nano plastics and microplastics, which can be easily ingested by aquatic species. When animals absorb such residues, they cause blockages in the digestive system, which makes it impossible for them to feed, resulting in the debilitation of individuals and often death (ARAÚJO et al., 2016).

The decomposition of organic materials from urban solid waste generates gases that can affect the environment. The release of biogas is a severe atmospheric problem and it has varying effects from the odor that spreads through the air (CHAVES et al., 2015). Although the effects of organic compounds, such as food, have not been calculated, the decomposition of these materials and paper will produce slurry, rich in heavy metals (lead, nickel, and cadmium) from electro-electronics, which affect soil and water (SOARES et al., 2007).

Another factor that can aggravate gases is burning, which is the most common method used to dispose of solid waste, especially in the dry season. This has implications for the health of the human populations that live nearby, as they end up inhaling effluents such as toxic gases, carbon monoxides, sulfur dioxide, ozone, and chlorine (BRANDÃO et al., 2018).

According to Matos (2010), from the transport of human-produced sediments to the aquatic environment there is an increase in water turbidity, interference in biogeochemical cycles, as well as changes 
in water direction and speed. This leads to changes in the substrate, which can interfere in the life cycle of aquatic animals, causing the accumulation of metals and toxic substances and the reduction of oxygen levels due to high rates of sedimentation and high concentrations of materials suspended in water. Another problem is the overflowing of rivers, streams, and/or lakes because they also block water courses (D'ÁVILA, 2018).

The disposal of untreated solid waste has become a global catastrophe, generating damage and pollution to the environment, affecting soil, water, and/or air (MOTA et al., 2009). Gouveia (2012) highlights that solid waste has become a social issue in recent years due to the problem it causes for the environment and human health. Thus, the irregular population growth around the Bate Estacas stream has had an adverse effect not only on the nearby residents but also on the fauna and flora, since the accumulation of solid waste that is deposited inadequately in this location contributes to the increase of visual pollution, as well as being carried to the stream bed during the rainy season.

One way to minimize these impacts is to raise awareness among populations, increase enforcement, and present alternative waste use and/or disposal methods. Awareness also needs to be introduced through new habits in order to generate changes in the behaviors of populations, with the aim of reducing the creation of unnecessary waste. For this, it is necessary to invest in the education of urban cleaning and pedagogical projects that teach the correct disposal of waste.

\section{CONCLUSIONS}

This study showed that the waste discarded in the Bate Estacas stream is predominantly composed of plastics in terms of quantity, however, construction materials were the heaviest waste objects. We estimate the disposal of approximately 3 tons of discarded material in $300 \mathrm{~m}^{2}$. The inadequate disposal of solid waste in the stream can directly compromise the quality and quantity of water, creating direct risks to the surrounding population's health. Actions aimed at cleaning and improving drainage should be prioritized at the most critical points of the stream.

\section{REFERENCES}

ARAÚJO, M. C. B.; COSTA, M. F.. Praias urbanas: o que há de errado com elas?. Revista Meio Ambiente e

Sustentabilidade, Curitiba, v.11, n.5, p.51-58, 2016.

ARAÚJO, M. C. B.; SILVA-CAVALCANTI, J. S.. Dieta indigesta: milhares de animais marinhos estão consumindo plásticos. Revista Meio Ambiente e Sustentabilidade, Curitiba v.10, n.5, 2016. DOI: http://dx.doi.org/10.22292/mas.v10i5.511

BARBOSA, R. P.; VIANA, V. J.. Recursos naturais e biodiversidade: preservação e conservação dos ecossistemas. São Paulo: Érica, 2014.

BENSUSAN, N.. Conservação da Biodiversidade em áreas protegidas. Rio de Janeiro: FGV, 2006.

BEZERRA, S. F.; JUSTINA, E. E. D.; SAMPAIO, S. F.; ARAUJO, M. S.. Diagnóstico, avaliação e monitoramento das áreas de risco na bacia do stream Grande - Porto Velho - RO. Geonorte, Manaus, v.1, n.4, p.599-611, 2012.

BILAC, R. P. R.; ALVES, A. M.. Crescimento urbano nas Áreas de Preservação Permanente (PPAS): um estudo de caso do leito do rio Apodi/Mossoró na zona urbana de Pau dos Ferros-RN. Geotemas, Pau dos Ferros, v.4, n.2, p.79-95, 2014. DOI: https://doi.org/10.33237/geotemas.v4i2.1261

BORGES, L. A. C.; REZENDE, J. L. P. R.; PEREIRA, J. A. A.; COELHO, L. M. C.; BARROS, D. A.. Áreas de preservação permanente na legislação ambiental brasileira. Ciência Rural, Santa Maria, v.41, n.7, p.1202-1210, 2011. DOI: https://doi.org/10.1590/S0103-84782011000700016

BRANDÃO, E. L. B.; BERNARDO, G. P.; BERNARDO, L. P.; NASCIMENTO, S. I. B.; LIMA, B. F. R.; SILVA K. V. C. C.; G. M. E.. Queima Inadequada de Resíduos Sólidos Domésticos, 
Principais Gases Tóxicos e Manifestações Clínicas: Uma Revisão de Literatura. Revista Multidisciplinar de Psicologia, v.12, n.42, p.602-612, 2018. DOI:

https://doi.org/10.14295/idonline.v12i42.1356

BRASIL. Constituição da República Federativa do Brasil de 1988. Brasília: DOU, 1988.

BRASIL. Lei n.12.651 de 25 de maio de 2012. Dispõe sobre a proteção da vegetação nativa; altera as Leis nos 6.938 , de 31 de agosto de 1981, 9.393, de 19 de dezembro de 1996, e 11.428, de 22 de dezembro de 2006; revoga as Leis nos 4.771, de 15 de setembro de 1965, e 7.754, de 14 de abril de 1989, e a Medida Provisória no 2.166-67, de 24 de agosto de 2001; e dá outras providências. Brasília: DOU, 2012.

CASTRO, S. L. I.; MAY, L. R.; GARCIAS, C. M.. Meio ambiente e cidades - Áreas de Preservação Permanente (PPAS) marginais urbanas na lei federal n. 12.651/12. Ciência Florestal, Santa Maria, v.28, n.3, p.1340-1349, 2018. DOI: https://doi.org/10.5902/1980509833353

CHAVES, G. G.; SOARES, F. R.; SEO, E. S. M.. Análise comparativa do desempenho ambiental de processos de destinação de resíduos sólidos urbanos com reaproveitamento energético. InterfacEHS, São Paulo, v.10, n.1, p.117-124, 2015.

CPRM. Serviço Geológico do Brasil. Uso e ocupação do solo e levantamento preliminar dos aspectos ambientais na região de Porto Velho - RO. Porto Velho, 1997.

D’ÁVILA, W. P. S.. Análise ambiental dos fatores de risco de inundação no rio Marinho - Grande Vitória, Espírito Santo. Revista Meio Ambiente e Sustentabilidade, Curitiba, v.14, n.7, p.74-89, 2018. DOI:

https://doi.org/10.22292/mas.v14i7.628

GARCIA, J. M.; MANTOVANI, P.; GOMES, R. C.; LONGO, R. M.; DEMAMBORO, A. C.; BETTINE, S. C.. Degradação ambiental e qualidade da água em nascentes de rios urbanos. Sociedade \& Natureza, v.30, n.1, p.228-254, 2018. DOI: https://doi.org/10.14393/SN-v30n1-2018-10

GUIMARÃES, B. B.; BRAGA, R.. Áreas de Preservação Permanente urbanas e as inundações em São João da Boa Vista/SP: observações sobre a aplicação do Código Florestal brasileiro no córrego São João. In: SIMPÓSIO BRASILEIRO DE GEOGRAFIA FÍSICA APLICADA, 27. Anais. Campinas: UNICAMP, 2017.

GOUVEIA, N.. Resíduos sólidos urbanos: impactos socioambientais e perspectiva de manejo sustentável com inclusão social. Ciência \& Saúde Coletiva, Rio de Janeiro, v.17, n.6, p.1503-1510, 2012. DOI: http://dx.doi.org/10.1590/S1413-81232012000600014

IBGE. Instituto Brasileiro de Geografia e Estatística. Cidades v4.4.17. Brasília: IBGE, 2020.

LONDE, P. R.; MENDES, P. C.. A influência das áreas verdes na qualidade de vida urbana. Hygeia: Revista Brasileira de Geografia Médica e da Saúde, v.10, n.18, p.264-272, 2014.

MATOS, F. C.. Caracterização qualitativa dos impactos ambientais causados pela ocupação urbana no stream do Tucunduba, Belém, PA. Dissertação (Mestre em Ciências
Ambientais) - Universidade de Taubaté, São Paulo, 2010.

MOREIRA, B. R.; OLIVEIRA, M. A.. Percepção ambiental de moradores do entorno de Áreas de Preservação Permanente em Porto Velho, Rondônia. South American Journal of Basic Education, Technical and Technological, Rio Branco, v.6, n.1, p. 213-226, 2019.

MOTA, J. C.; ALMEIDA, M. M.; ALENCAR, V. C.; CURI, W. F.. Características e impactos ambientais causados pelos resíduos sólidos: uma visão conceitual. In: CONGRESSO INTERNACIONAL DE MEIO AMBIENTE SUBTERRÂNEO, 1. Anais. São Paulo: ABAS, 2009.

NASCIMENTO, C. P.; SANTOS, C.; SILVIA M.. Porto Velho: a produção do espaço urbano de Rondônia (1980/2010).

Geografar, Curitiba, v.7, n.1, p.20-52, 2012. DOI: http://dx.doi.org/10.5380/geografar.v7i1.22447

NOVA, F. V. P. V.; TENÓRIO N. B.. Doenças de veiculação hídrica associadas à degradação dos recursos hídricos, município de Caruaru-PE. Caminhos da Geografia, v.20, n.71, p.250-264, 2019. DOI: https://doi.org/10.14393/RCG207145545

OJEDA, K.; SIQUEIRA, F. M. B.; PINTO, A. A. S.. Diagnóstico ambiental da Área de Preservação Permanente no alto curso do córrego do São Gonçalo, Cuiabá-MT. In: CONGRESSO BRASILEIRO DE GESTÃO AMBIENTAL, 4. Anais. Salvador: IBEAS, 2013.

PEREIRA, U. A.; ALEIXO, N. C. R.. Os resíduos sólidos urbanos como condicionante de doenças na cidade de Manaus - AM. Geonorte, Manaus, v.9, n.31, p.32-53, 2018. DOI: http://doi.org/10.21170/geonorte.2018.V.9.N.31.32.53

RODRIGUES, J. B.; SILVA, D. D. S.; SALES, L. L. N.; CANTANHEDE, K. M. C.; FREITAS, S. J. N.; CABRAL, A. C. L. C.; ALVES, B. S.; SILVA, J. C. A.; GONÇALVES JÚNIOR, F. A.; SILVA, A. C.. Levantamento e caracterização dos impactos ambientais na área de preservação do Itapiracó, São Luís/MA. Nature and Conservation, v.13, n.4, p.31-36, 2020. DOI: http://doi.org/10.6008/CBPC2318-2881.2020.004.0004

ROMEIRO, A. R.. Desenvolvimento sustentável: uma perspectiva econômico-ecológica. Estudos Avançados, São Paulo, v.26, n.74, p.66-92, 2012. DOI: https://doi.org/10.1590/S0103-40142012000100006

ROSSI, W.; BRANCO, L. C.; LACERDA, J. A.; GOMES, A. C.; WAGNER, E. M. S.. Fontes de poluição e o controle da degradação ambiental dos rios urbanos em Salvador. Revista Interdisciplinar de Gestão Social, v.1, n.1, p.61-74, 2012. DOI: http://dx.doi.org/10.9771/23172428rigs.v1i1.12068

SAMPAIO, S.; JUSTINA, E. E. D.; BEZERRA, S. F..

Características socioeconômicas dos moradores de área de risco da bacia do stream Grande-Porto Velho (RO). Geonorte, Manaus, v.1, n.4, p.501-514, 2012.

SANTOS, M. F.; MARTINS, O. D. C.; SILVA BRITO, F. L.; BRITO, C. P.; PEREIRA, R. L.. Impactos ambientais no stream Caranã, Boa Vista-RR. Geonorte, Manaus, v.10, n.1, p.485-489, 2014.

SANTOS, J. W. M. C.; LOVERDE-OLIVEIRA, S. M.;

ANGEOLETTO F.; PESSI D. D.; ALVES, G. B. M.. Diagnóstico de impactos na Área de Preservação Permanente do arroio 
urbano Arareau, Rondonópolis, Brasil. Revista Geográfica Venezolana, Mérida, v.60, n.2, p.300-312, 2019.

SCHÄFFER, W. B.; ROSA, M. R.; AQUINO, L. C. S.; MEDEIROS, J. D.. Áreas de Preservação Permanente e Unidades de Conservação X Áreas de Risco. O que uma coisa tem a ver com a outra?. Brasília: MMA, 2011.

SILVA, E. A.; TORRE, M. B. R.. Disposição de resíduos sólidos urbanos: um estudo de caso a partir das concepções de moradores das comunidades de Moranguinho/Metrô, Areia Branca-RN. Revista Brasileira de Gestão Ambiental, Mossoró, v.2, n.1, p.06-25, 2008.

SILVA, M. J. S. O.; SILVA FILHO, J. A.; SILVA, Á. J. L.. Principais impactos e mudanças na paisagem decorrentes da ocupação desordenada no município de Encanto -RN: exemplo do bairro Alto da Boa Vista. Revista do CERES, Caicó, v.1, n.2, p.115-121, 2015.

SILVA NETO, V. L.; FERREIRA, D. F.; SOUZA, P. A.; VIOLA, M. R.. Diagnóstico ambiental da Área de Preservação Permanente no alto curso do córrego Dois Irmãos em Gurupi-TO. Enciclopédia Biosfera, Jandaia, v.13 n.23, p.470486, 2016.
SILVA, H. R. O., GUIMARÃES, S. C. P.; OLIVEIRA L. B.. O uso do geoprocessamento na espacialização e avaliação das Áreas de Preservação Permanente: Cidade de Porto Velho-RO. Confins, São Paulo, v.1, n.30, 2017. DOI: https://doi.org/10.4000/confins.11764

SOARES, L. G. C.; SALGUEIRO, A. A.; GAZINEU, M. H. P.. Educação ambiental aplicada aos resíduos sólidos na cidade de Olinda, Pernambuco - um estudo de caso. Revista Ciências \& Tecnologia, v.1, n.1, p.1-9, 2007.

SZEREMETA, B.; ZANNIN, P. H. T.. A importância dos parques urbanos e áreas verdes na promoção da qualidade de vida em cidades. Ra'e Ga, Curitiba, v.29, p. 177-193, 2013.

UCHÔA, A. S. N.; PROCHNOW, T. R.. Estudo de caso sobre a degradação do ecossistema no stream Pricumã, com alunos do ensino fundamental. Areté, Manaus, v.6, n.10, p.116-131, 2013.

ZÜNDT, C.. Baixada Santista: uso, expansão e ocupação do solo, estruturação de rede urbana regional e metropolização. In: CUNHA, J. M. P.. Novas metrópoles paulistas: população, vulnerabilidade e segregação. Campinas: Unicamp, 2006. p.305-363.

A CBPC - Companhia Brasileira de Produção Científica (CNPJ: 11.221.422/0001-03) detém os direitos materiais desta publicação. Os direitos referem-se à publicação do trabalho em qualquer parte do mundo, incluindo os direitos às renovações, expansões e disseminações da contribuição, bem como outros direitos subsidiários. Todos os trabalhos publicados eletronicamente poderão posteriormente ser publicados em coletâneas impressas sob coordenação da Sustenere Publishing, da Companhia Brasileira de Produção Científica e seus parceiros autorizados. Os (as) autores (as) preservam os direitos autorais, mas não têm permissão para a publicação da contribuição em outro meio, impresso ou digital, em português ou em tradução. 